\title{
Prognostic relevance of HSP70 antigen and antibody measurement in patients with acute myeloid leukemia of intermediate and unfavorable cytogenetic risk
}

\author{
Jarosław Piszcz ${ }^{1}$, Łukasz Bolkun'1, Edyta Cichocka', \\ Marzenna Galar ${ }^{1}$, Adam Hołownia², Janusz Kłoczko \\ 1 Department of Hematology, Medical University of Bialystok, Białystok, Poland \\ 2 Department of Clinical Pharmacology, Medical University of Bialystok, Białystok, Poland
}

\section{KEY WORDS}

acute myeloid

leukemia, anti-HSP70 antibody, heat shock protein, HSP70

\begin{abstract}
INTRODUCTION Heat shock proteins (HSPs) are overexpressed in many types of cancers and are implicated in tumor cell proliferation, differentiation, invasion, metastasis, death, and recognition by the immune system. It has been postulated that the HSP70 protein can be used as a prognostic indicator of overall patient survival in many types of cancer including leukemia.

OBJECTIVES The aim of the study was to evaluate the concentrations of anti-HSP70 antibody and its antigen in the peripheral blood of patients with acute myeloid leukemia (AML), as well as to assess the usefulness of this measurement.

PATIENTS AND METHODS The study included 80 patients with AML of intermediate and high cytogenetic risk, scheduled for allogenic stem cell transplantation after initial intensive chemotherapy. Plasma concentrations of anti-HSP70 antibodies and HSP70 antigen were measured by enzyme-linked immunosorbent assay. The antigen was additionally measured by Western blot analysis. The control group consisted of healthy subjects.

RESULTS Patients with AML had significantly higher anti-HSP70 antibody concentrations compared with the control group. The concentration of HSP70 antigen as well as anti-HSP70 antibody showed no associations with the type of response after induction chemotherapy. However, patients with higher antigen levels and lower anti-HSP70 antibody levels had significantly shorter overall survival.

CONCLUSIONS The study suggests that anti-HSP70 antibodies and HSP70 antigen may be valuable indicators of a poor prognosis in patients with AML.
\end{abstract}

INTRODUCTION Heat shock proteins (HSPs) constitute a family of highly conserved proteins responsible for cell protection on exposure to various types of stress. ${ }^{1,2}$ Found both in normal and cancer cells, they are capable of stabilizing proteins and polypeptides and presumably participate in signal transduction pathways of different cell regulators. ${ }^{3}$ In contrast to normal cells, the expression of HSPs is strongly elevated in most cancer cells. ${ }^{1-3}$ This apparently helps protect them from otherwise harmful conditions, and judging from the increased activity of HSPs in aggressive tumors, leads to carcinogenesis. ${ }^{4-9}$ Conversely, as illustrated in experimental models, the down-regulation of HSP70 decreases tumorigenicity. ${ }^{10}$

A dual function of HSP70 is strongly correlated with its intracellular or membrane location. On the one hand, HSP70 participates in the folding of newly synthesized polypeptides and promotes cell survival in otherwise lethal conditions through inhibition of the apoptotic pathway at multiple levels. ${ }^{11-13}$ On the other hand, by being present primarily on tumor cells as opposed to normal cells, it provides a recognition structure for 
TABLE 1 Characteristics of patients with acute myeloid leukemia $(n=80)$

\begin{tabular}{ll} 
Characteristics & Value \\
age, $y$ & $48.2(18-60)$ \\
\hline unfavorable cytogentic risk & $25(31.1)$ \\
\hline intermediate cytogenetic risk & $55(68.9)$ \\
\hline white blood cell count, G/l & $33.56 \pm 8.12$ \\
\hline blastic cells in peripherial blood, \% & $52.3 \pm 5.35$ \\
\hline blastic cells in bone marrow, \% & $55.54 \pm 3.98$ \\
\hline French-American-British classification & 80 \\
\hline M0 & $5(6.25)$ \\
\hline M1 & $4(5)$ \\
\hline M2 & $39(48.75)$ \\
\hline M4 & $17(21.25)$ \\
\hline M5 & $15(18.75)$ \\
\hline M6 & $0(0)$ \\
\hline M7 & $0(0)$ \\
\hline
\end{tabular}

Data are presented as mean \pm standard deviation, number (percentage), median (minimum-maximum). classified as: favorable (t, $[15,17], \mathrm{t},[8,21]$, or solely inv16); unfavorable $(-5,-7$, or complex $[\geq 3]$ abnormalities), or intermediate (all others) according to the Southwest Oncology Group..$^{20,21}$ Samples were collected from all newly diagnosed AML patients younger than 60 years, but to preserve the uniformity of the study group, patients with favorable cytogenetic outcome owing to different biology and result of specific treatment, were excluded from the study. Patients were treated at the Hematology Department of the Medical University of Bialystok, Poland, with a standard therapy for patients younger than 60 years, based on the Polish Adult Leukemia Group protocol. ${ }^{22}$ They underwent a 7-day induction therapy, in which cytarabine $\left(200 \mathrm{mg} / \mathrm{m}^{2}\right)$ was administered as a continuous IV infusion for 7 consecutive days; daunorubicin $\left(60 \mathrm{mg} / \mathrm{m}^{2}\right)$ was administered for 3 consecutive days as an IV push; and cladribine $\left(5 \mathrm{mg} / \mathrm{m}^{2}\right)$ was administered for 5 days also as an IV push. ${ }^{22}$ Patients who achieved complete remission were given 2 consolidation therapies (1st HAM: cytarabine [1.5 g/m² IV, 1-3 days] and mitoxantrone $\left[10 \mathrm{mg} / \mathrm{m}^{2} \mathrm{IV}, 3-5\right.$ days] and 2nd HDArC as a high dose of cytarabine [ $4 \mathrm{~g} /$ $\mathrm{m}^{2} / \mathrm{d}$ IV in 1, 3, 5 day]) prior to hematopoietic stem-cell transplantation. The median follow-up of patients from day 1 of induction therapy was 233 days (min., 5; max., 1958).

The control group consisted of 90 age- and sex-matched healthy subjects.

Plasma was separated from EDTA peripheral blood samples by centrifuging the samples at $5000 \mathrm{rpm}$ for $10 \mathrm{~min}$. Plasma samples obtained from all study subjects were aliquoted and stored at $-70^{\circ} \mathrm{C}$ until the analysis.

Measurements of selected parameters HSP70 Western blot analysis The recombinant human HSP70 antigen (Sigma, United States) was used in the analysis. Protein was heated at $70^{\circ} \mathrm{C}$ for $10 \mathrm{~min}$ in a reducing sample buffer, separated on $4 \%-12 \% \mathrm{NuPage}^{\mathrm{TM}} \mathrm{Bis}$ Tris gel (Invitrogen, Carlsbad, California, United States) and transferred to a nitrocellulose membrane (Invitrogen) using the Trans-Blot SD transfer apparatus. Following transfer, membranes were incubated in a blocking buffer ( $5 \%$ nonfat dry milk plus Tris buffered saline containing $0.05 \%$ Tween 20 , TBS-T) for $1 \mathrm{~h}$ at room temperature and incubated for $1 \mathrm{~h}$ with the patients' plasma diluted at 1:100 in a blocking buffer. As a positive control, antihuman HSP70 antibody (EKS 750-P2 kit, Stressgen Biotechnologies, San Diego, California, United States), membranes were washed 4 times for $10 \mathrm{~min}$ in TBS-T, and then incubated for $1 \mathrm{~h}$ with peroxidase conjugated goat antihuman immunoglobulin G (IgG, KPL, Gaithersburg, Maryland, United States) diluted at 1:5000. Following incubation with secondary antibodies, membranes were washed 4 times for $10 \mathrm{~min}$ in TBS-T and developed in 3,3',5,5' tetramethylbenzidine substrate for 10 to $15 \mathrm{~min}$. At the end of color development, the substrate was removed and reaction stopped by washing the membrane with deionized water. 
TABLE 2 Spearman correlation of anti-HSP70 antibodies and HSP70 antigen with clinical and hematological parameters in patients with acute myeloid leukemia

\begin{tabular}{lll} 
& HSP70 antigen & Anti-HSP70 antibody \\
age & rho $=0.27, P=0.12$ & rho $=0.18, P=0.18$ \\
\hline white blood count & rho $=0.12, P=0.62$ & rho $=0.18, P=0.25$ \\
\hline peripheral blood blasts, $\%$ & rho $=0.18, P=0.30$ & rho $=-0.27, P=0.07$ \\
\hline bone marrow blasts, $\%$ & rho $=0.11, P=0.46$ & rho $=-0.18, P=0.29$ \\
\hline lactate dehydrogenase & rho $=0.24, P=0.19$ & rho $=-0.13, P=0.44$ \\
\hline CD13+ & rho $=-0.12, P=0.43$ & rho $=-0.03, P=0.87$ \\
\hline CD33+ & rho $=-0.11, P=0.51$ & rho $=-0.07, P=0.65$ \\
\hline CD34+ & rho $=-0.05, P=0.74$ & rho $=-0.26, P=0.15$ \\
\hline CRP & rho $=-017, P=0.25$ & rho $=-0.24, P=0.13$ \\
\hline
\end{tabular}

The control group for Western blot was pooled plasma of healthy volunteers. Antigen concentrations in individual patients are shown as a percentage (\%) concentration of antigen pooled plasma controls.

Detection of antihuman HSP70 $\lg$ G/A/M antibodies by an enzyme-linked immunosorbent assay Quantitative determination of antihuman HSP70 antibodies in the plasma was done using a commercial test kit (anti-HSP70 Elisa Kits, Stressgen Biotechnologies, USA) in accordance with the manufacturer's instructions.

Statistical analysis Descriptive statistics as well as univariate and multivariate analyses were performed. Relationships between continuous variables were assessed using Spearman rank correlations. The $\chi^{2}$ or Kruskal-Wallis test was used to assess the relationships between categorical variables. The Kaplan-Meier plots of survival were performed separately for each group. Cut-off points used for Kaplan-Meier plots were medians for each group. Survival curves were compared using the Cox's F test. A multivariate analysis using a multiple logistic regression was performed to predict mortality. All $P$ values were 2-tailed and considered statistically significant at a value of less than 0.05 .

RESULTS Patients We studied 80 adult patients with de novo AML before induction chemotherapy. There were 49 men and 31 women. The median age was 48 years (range, $18-60$ years). According to the FAB classification, 5 patients were identified as M0, 4 as M1, 39 as M2, 17 as M4, 15 as M5. A chromosomal analysis was performed in all patients. Patient characteristics are presented in TABLE 1.

The study showed no significant differences either in the mean anti-HSP70 antibody concentration or in the HSP70 antigen level in the different subgroups of AML $(P=0.34$ and $P=0.58$, respectively).

High concentrations of anti-HSP70 and HSP70 antigen in acute myeloid leukemia We measured the plasma concentration of HSP70 antigen and anti-
-HSP70 antibodies in a prospectively identified cohort of 80 patients with AML.

Patients with AML had a significantly higher concentration of anti-HSP70 antibodies compared with healthy controls $(354.62 \pm 21.3 \mathrm{pg} / \mathrm{ml}$ and $247.59 \pm 16.04 \mathrm{pg} / \mathrm{ml}$, respectively, $P=0.007$ ) The mean percentage of HSP70 antigen concentration (relative to controls) in AML patients was $109.81 \% \pm 10.17 \%$.

Correlation with clinical and laboratory data We evaluated the association of the HSP70 concentration with several clinical and hematological variables. In patients with $\mathrm{AML}$, no difference between the mean values of HSP70 antigen in the groups with an intermediate and unfavorable cytogenetic risk was noted $(119.16 \% \pm 17.36 \%$ and $103.13 \% \pm 11.08 \%$, respectively, $P=0.7$ ). Complete response was obtained in 44 of 80 patients (55\%). The study did not show any significant associations between the baseline HSP70 antigen level and the type of response after induction chemotherapy. The HSP70 antigen level in the group of AML patients with complete remission (CR) was $98.19 \% \pm 1.73 \%$, and in the remaining patients (no CR), it was $118.84 \% \pm 16.47 \%, P=0.55$.

We subsequently correlated HSP70 with a selection of well-known parameters of prognosis and tumor load in AML (TABLE 2). The study did not show any significant correlations with lactate dehydrogenase (LDH) and white blood cell count (WBC). The HSP70 level did not correlate with age, sex, the amount of blast cells in the peripheral blood and bone marrow, or cluster of difference (CD) markers (TABLE 2).

The analyses of anti-HSP70 antibodies in patients with AML did not reveal any significant differences between the concentration of anti-HSP70 antibodies in the group of patients with intermediate and unfavorable cytogenetic risk $(3029.83 \pm 29.51 \mathrm{pg} / \mathrm{ml}$ and $384.56 \pm 32.05 \mathrm{pg} / \mathrm{ml}$, respectively, $P=0.23)$. Additionally, no differences in the concentration of anti-HSP70 antibodies associated with the type of response after induction treatment were observed. The mean concentration of anti-HSP70 antibodies in CR patients showed be roughly equal to that of non-CR patients $(350.86 \pm 32.69 \mathrm{pg} / \mathrm{ml}$ and $357.53 \pm 28.77 \mathrm{pg} / \mathrm{ml}$, respectively, $P=0.88$ ). Furthermore, the anti-HSP70 antibody concentration did not correlate significantly with any parameters of prognosis and tumor load in AML (TABLE 2).

Although cytogenetic grouping did not correlate with the HSP70 antigen or its antibody in patients with AML, those with a low anti-HSP70 antibody concentration had a considerably shorter survival ( $P=0.03$; FIGURE 1). The median survival was 127 days for patients with a lower baseline anti-HSP70 antibody concentration than the median (354.62 pg/ml). The median survival of AML patients with a higher concentration of anti-HSP antibodies than the median was not reached at the time of the analyses. Of note, no 
FIGURE 1 Association

of the anti-

-HSP70 antibody

concentration with

overall survival in

patients with acute

myeloid leukemia.

The cumulative

proportions of survivors

with the baseline anti-

-HSP70 antibody

concentration lower than

or equal to the median

(continuous line) and

higher than the median

(dashed line) are shown.

The curves are

significantly different

$(P=0.03)$

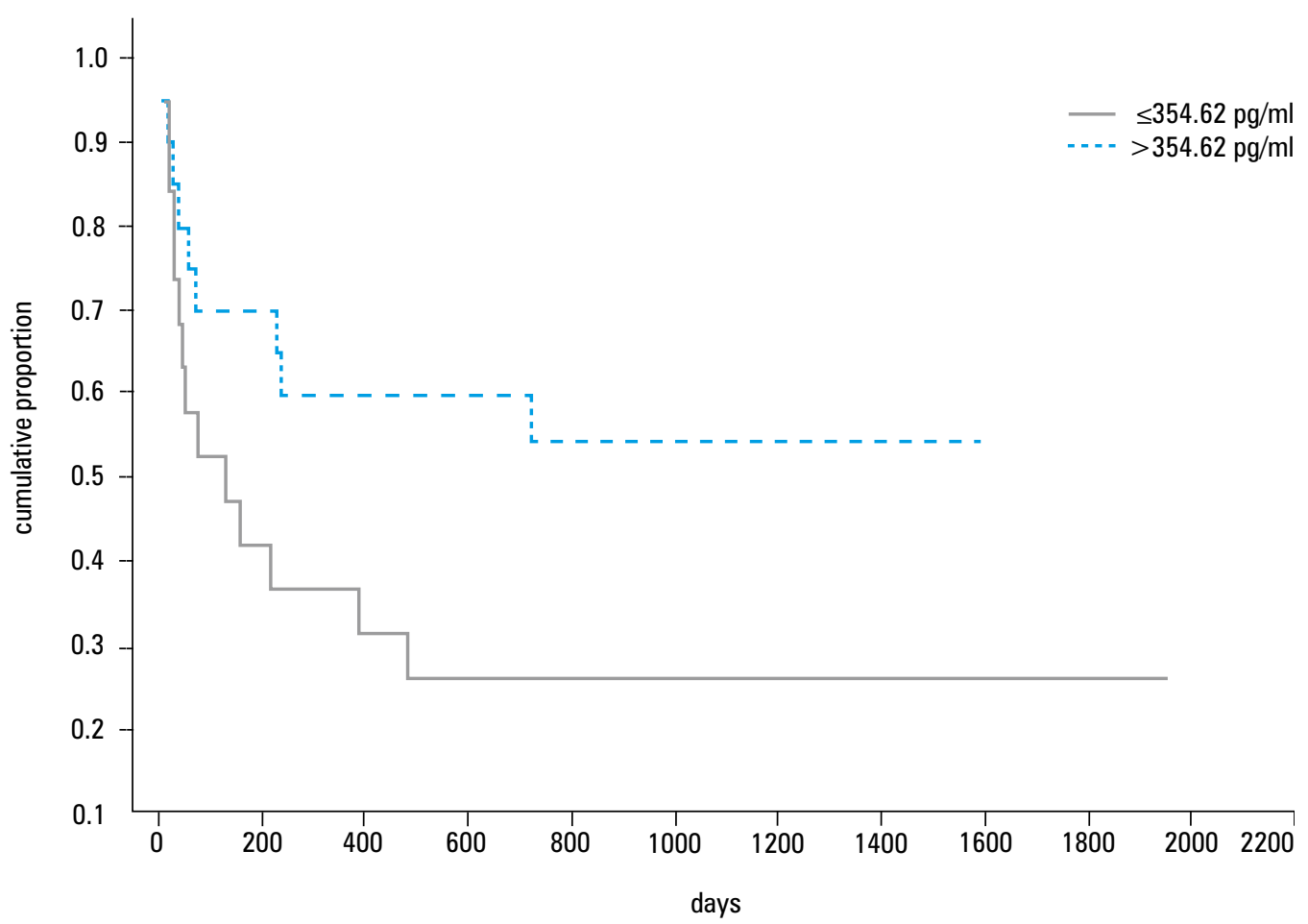

differences in survival were found in patients with AML according to the median HSP70 antigen level (109.81\%). The median survival for patients with higher level than the median was 69 days compared with 214 days for patients with lower levels $(P=0.15$; FIgURE 2$)$.

A multivariate analysis was performed to assess the effect of HSP70 protein and anti-HSP70 antibodies on the risk of death in the study group. The logistic regression analysis revealed that a higher HSP70 protein concentration and lower anti-HSP70 antibody level predicted death with a relative risk of 8.5 (95\% confidence interval, 1.8-39.2, $P=0.022$ ). These 2 parameters were the best predictors of the alive/dead status of patients in the study group $\left(R^{2}=0.379\right)$.

DISCUSSION Normal development of hematopoietic cells and maintenance of tissue homeostasis require a relatively tight regulation of proliferation, differentiation, and death processes. Any minor deregulation of the above can result in leukemia. ${ }^{23}$ Abnormal HSP expression has recently been reported to disrupt cellular development, which draws particular attention to HSP70 as a potential anticancer target. HSPs are overexpressed in a wide range of human cancers and are implicated in tumor cell proliferation, differentiation, invasion, metastasis, death, and recognition by the immune system. Although HSP levels are not informative at the diagnostic level, they are more restricted molecular markers that are quite useful in diagnostic immunopathology and carcinogenesis. On the other hand, the circulating levels of HSP and anti-HSP antibodies in cancer patients may be helpful in tumor diagnosis. Furthermore, some studies have shown an association between HSPs and poor differentiation in cancers of the breast, ovary, and oral epithelium, as well as lung carcinomas and astrocytomas. ${ }^{24} \mathrm{HSP} 70$ has also been proved to be involved in increased cell proliferation (breast, uterine cervix, lung), lymph node metastasis (breast, colon), increased tumor size (uterine, cervix), the presence of mutated p53 (breast, endometrium), and a higher clinical stage (oral, colon, melanoma). ${ }^{24}$ Moreover, high HSP70 levels predicted a lower response of breast cancers to radiation and hyperthermia, ${ }^{25}$ as well as resistance to conventional treatment with dexamethasone in multiple myeloma cells. ${ }^{26}$

Few data are available regarding the expression or concentration of HSPs in AML. ${ }^{19,27}$ Thomas et al. ${ }^{19}$ reported that leukemic cells showed a heterogeneous pattern of HSP70 expression. The expression assessed by flow cytometry ranged from $3 \%$ to $97 \%$ (median, 34\%) among patients and was not specific to any subtype of AML. The analysis showed that the expression of HSP70 on blasts of less than $20 \%$ correlated with higher $\mathrm{CR}$ rates and longer overall survival. The expression was not different between the subgroups with favorable and unfavorable cytogenetic risk. Furthermore, it was established that HSP70 protein positively correlated with the BCL2 oncoprotein. The study group did not receive uniform treatment but the authors postulated that worse prognosis, in term of the overall survival, might be a consequence of elevated antiapoptotic protein expression.

Our study was performed in a cohort of AML patients receiving uniform treatment and we assessed circulating HSP70 antigen. The analysis showed a higher amount of HSP70 protein in AML individuals than in healthy controls. Although the level of HSP70 protein in the peripheral blood may correlate with intracellular expression, ${ }^{28}$ and therefore with overall survival, we did 
FIGURE 2 Association of the HSP70 antigen level (relative to control) with overall survival in patients with acute myeloid leukemia. The cumulative proportions of survivors with the baseline antigen HSP70 level lower than or equal to the median (continuous line) and higher than the median (dashed line) are shown. The curves are not significantly different $(P=0.15)$.

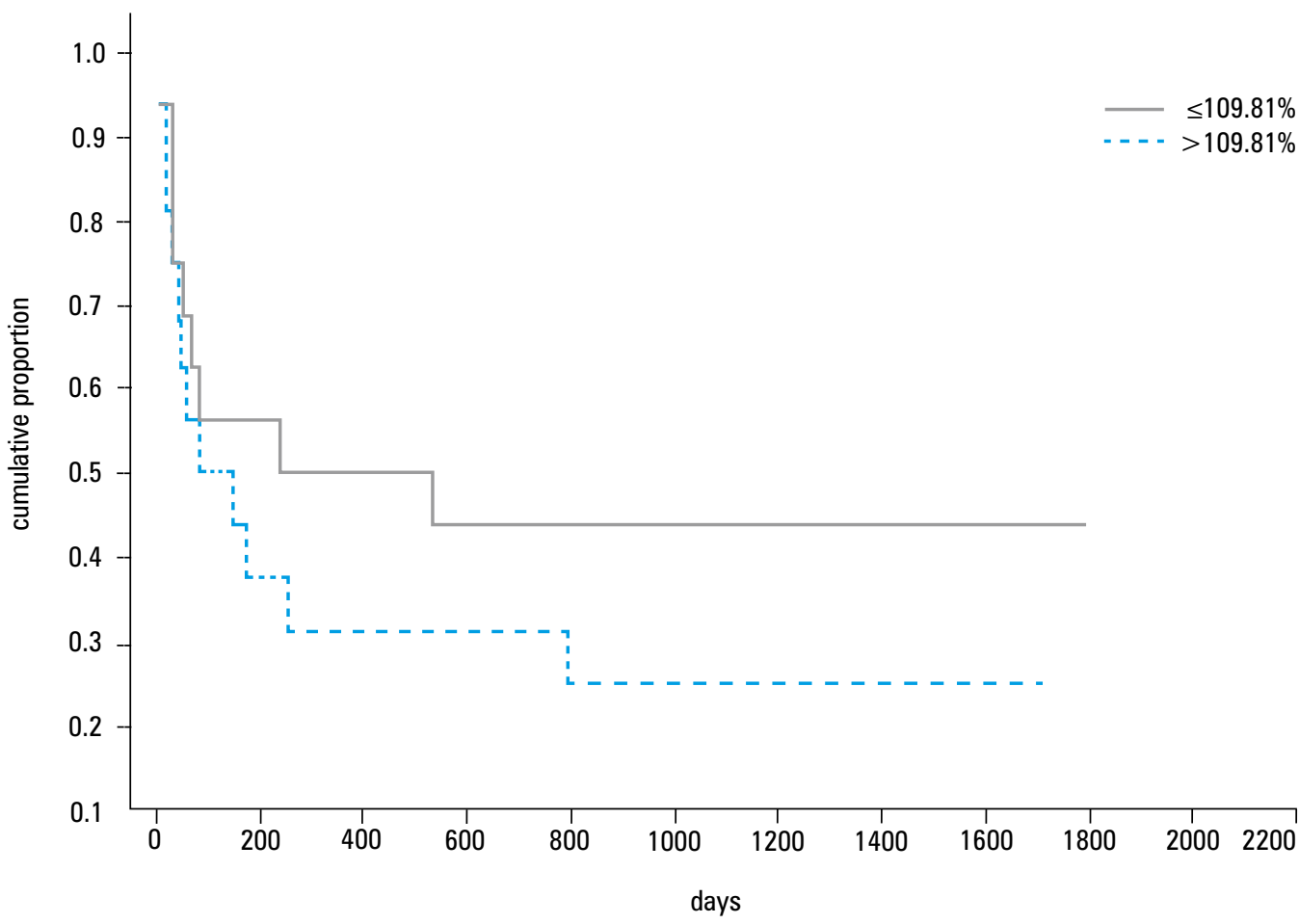

not notice any statistically significant prolongation of the overall survival in the group with a lower HSP70 concentration. On the other hand, we observed a better median overall survival in that group but lack of statistical significance may be related to the limited number of patients. Furthermore, logistic regression showed the effect of the HSP70 concentration on the alive/dead status that could reflect a prognostic value of this parameter. We did not observe a different HSP70 concentration according to cytogenetic grouping, which is consistent with the study by Thomas et al. ${ }^{19}$

Circulating HSP of HSP70 in myeloid neoplasms had previously been analyzed by Yeh et al. ${ }^{20}$ Similar to our study, their study revealed that AML patients had a high plasma level of the HSP70 antigen in contrast to healthy controls. Moreover, patients with higher circulating HSP70 levels had a significantly shorter survival compared with the remaining study population. The authors did not show significant differences in the concentration between the subgroups with different cytogenetic risk but revealed that the HSP70 antigen positively correlated with such risk factors as WBC, $\beta_{2}$-microglobulin, and $\mathrm{LDH}$, which have a known prognostic value and are associated with adverse outcomes in AML. ${ }^{20}$ In contrast, our study did not show any correlations with the above prognostic factors.

The effect of HSP70 on overall survival shown in previous studies may have other explanation than that postulated by Thomas et al. ${ }^{19}$ As shown in a recent study by Reikvam et al., ${ }^{29} \mathrm{pa}-$ tients harboring an FLT3-internal tandem duplication (FLT3-ITD) were extensively overrepresented in the cluster with high HSP levels, indicating a strong dependence of HSPs in stabilizing FLT3-ITD encoded oncoproteins. Moreover, FLT3 ligation further increased the levels of HSP90 and its co-chaperone, HSP70. ${ }^{29} \mathrm{Un}$ fortunately, in our study, molecular tests did not reveal the FLT3-ITD mutation in any of the patients; therefore, we cannot confirm or disprove the above findings. ${ }^{29}$

Although high intracellular HSP70 levels contribute to cell protection mechanisms, the tumor-specific membrane-associated HSP70 expression has been shown to function as a danger signal that can increase the immunogenicity of a tumor and induce natural killer cell and cytotoxic T lymphocyte responses. ${ }^{13,30}$ More importantly, the secretion of HSP70 has shown to be the consequence of immune responses, thus placing HSP70 among the dominant antigens recognized by the immune system. HSP70 released from tumor cells may allow the transfer of antigenic peptides to antigen presenting cells or may enhance the ability of antigen-presenting cells to process and present tumor antigens to specific $\mathrm{T}$ cells, thereby augmenting the immune responses. ${ }^{31,32}$ Thus, the plasma anti-HSP70 antibody concentration could also indicate both innate and adaptive immunity as well as tumor load.

The first report of antibodies against HSPs in a human disease is that of Jarjour et al., ${ }^{33}$ who suggested that the difference between the levels of anti-HSPs antibodies seen in the blood of patients with various rheumatoid and other inflammatory diseases and that of normal controls could merely reflect disease-associated polyclonal B-cell activation..$^{33}$ Since then, a few investigations on the presence of anti-HSPs antibodies in the tumor process have been conducted. For example, Conroy et al., ${ }^{34}$ showed that antibodies against HSPs, including HSP70, were detectable in patients with breast cancer, and suggested that increased levels of antibodies to HSP27 were correlated with an improved survival rate, whereas 
high levels of antibodies to HSP90 were correlated with a reduced survival rate. ${ }^{34}$ Korneeva et al. ${ }^{35}$ also reported that there was a common prevalence of anti-HSP27 IgA (but not IgG) antibodies in the genital tract of women with endometrial and ovarian cancer before and after treatment.

Our study demonstrated a higher concentration of anti-HSP70 antibodies in AML patients in comparison with healthy controls. Additionally, it did not show any differences in the baseline concentration of anti-HSP70 in the subgroups of different cytogenetic risk, and did not reveal any statistical differences in the concentration of the anti-HSP70 antibody and the response rate. However, we showed a significantly longer overall survival in patients with a higher concentration of anti-HSP70 antibody in contrast to patients with a lower concentration of the protein at the time of diagnosis. Furthermore, our multivariate analysis revealed that the anti-HSP70 antibody concentration together with the plasma HSP70 level were the best predictors of the alive/ dead status in patients with AML. The study did not show any correlation between the anti-HSP concentration and laboratory parameters linked with tumor mass.

In conclusion, the expression of HSP70 in patients with AML may play a role in the resistance of cancer cells to immune-mediated destruction. However, in some patients, this could stimulate an immune response that may contribute to the fight against malignant cells and promote better overall outcome of therapy. It still remains unclear whether extracellular HSP70 is released as a free soluble protein, in detergent-soluble membrane vesicles, or in HSP70-peptide complexes, and whether it regulates the role of antibodies in response to the antigen. Further research is needed to determine the nature and form of the HSP70 antibodies and antigen. Nevertheless, their clinical significance as an adverse prognostic indicator of survival in patients with AML in our study is remarkable. Additional analyses are necessary to better understand the role of anti-HSP70 antibodies and HSP70 antigen in the prognosis of leukemia and prediction of therapeutic response.

Acknowledgements The study was supported by research grant of Medical University of Bialystok (grant number, 3-52697L; granted to J.P.).

\section{REFERENCES}

1 Hartl FU, Hayer-Hartl M. Molecular chaperones in the cytosol: from nascent chain to folded protein. Science. 2002; 295: 1852-1858.

2 Jolly C, Morimoto RI. Role of the heat shock response and molecular chaperonesin oncogenesis and cell death. J Natl Cancer Inst. 2000; 92: 1564-1572.

3 Creagh EM, Sheehan D, Cotter TG. Heat shock proteins: modulators of apoptosis in tumour cells. Leukemia. 2000; 14: 1161-1173.

4 Kojika S, Sugita K, Inukai T, et al. Mechanisms of glucocorticoid resis tance in human leukemic cells: implication of abnormal 90 and $70 \mathrm{kDa}$ hea shock proteins. Leukemia. 1996; 10: 994-999.

$5 \mathrm{Kim}$ SH, Yeo GS, Lim YS, et al. Suppression of multidrug resistance via inhibition of heat shock factor by quercetin in MDR cells. Exp Mol Med. 1998; 30: 87-92
Konno A, Sato N, Yagihashi A, et al. Heat or stress-inducible transformation-associated cell surface antigen on the activated $\mathrm{H}$-ras oncogene-transfected rat fibroblast. Cancer Res. 1989; 49: 6578-6582.

7 Mosser DD, Caron AW, Bourget L, et al. Role of the human heat shock protein hsp70 in protection against stress-induced apoptosis. Mol Cell Biol. 1997; 17: 5317-5327.

8 Mehlen P, Schulze-0sthoff K, Arrigo AP. Small stress proteins as novel regulators of apoptosis. Heat shock protein 27 blocks Fas/APO-1- and staurosporine-induced cell death. J Biol Chem. 1996; 271: 16510-16514.

9 Garrido C, Ottavi P, Fromentin A, et al. HSP27 as a mediator of influence-dependent resistance to cell death induced by anticancer drugs. Cancer Res. 1997; 57: 2661-2667.

10 Gurbuxani S, Bruey JM, Fromentin A, et al. Selective depletion of inducible HSP70 enhances immunogenicity of rat colon cancer cells. Oncogene. 2001; 20: 7478-7485.

11 Hartl FU, Hayer-Hartl M. Molecular chaperones in the cytosol: from nascent chain to folded protein. Science. 2002; 295: 1852-1858.

12 Jolly $\mathrm{C}$, Morimoto RI. Role of the heat shock response and molecular chaperones in oncogenesis and cell death. J Natl Cancer Inst. 2000; 92 1564-1572.

13 Schmitt E, Gehrmann M, Brunet M, et al. Intracellular and extracellular functions of heat shock proteins: repercussions in cancer therapy. J Leukocyte Biol. 2007; 81: 15-27.

14 Multhoff G, Botzler C, Wiesnet M, et al. A stress-inducible 72-kDa heat-shock protein (HSP72) is expressed on the surface of human tumor cells, but not on normal cells. Int J Cancer. 1995; 61: 272-279.

15 Gehrmann M, Schmetzer H, Eissner G, et al. Membrane-bound hea shock protein 70 ( Hsp70) in acute myeloid leukemia: a tumor specific recognition structure for the cytolytic activity of autologous NK cells Haematologica. 2003; 88: 474-476.

16 Calderwood SK, Mambula SS, Gray Jr PJ, et al. Extracellular heat shock proteins in cell signaling. FEBS Lett. 2007; 581: 3689-3694.

17 Barreto A, Gonzalez JM, Kabingu E, et al. Stress-induced release of HSC70 from human tumors. Cell Immunol. 2003; 222: 97-104.

18 Broquet AH, Thomas G, Masliah J, et al. Expression of the molecuar chaperone Hsp70 in detergent-resistant microdomains correlates with its membrane delivery and release. J Biol Chem. 2003; 278: 21601-21606.

19 Thomas X, Campos L, Mounier C, et al. Expression of heat-shock proteins is associated with major adverse prognostic factors in acute myeloid leukemia. Leuk Res. 2005; 29: 1049-1058.

20 Yeh $\mathrm{CH}$, Tseng $\mathrm{R}$, Hannah A, et al. Clinical correlation of circulating heat shock protein 70 in acute leukemia. Leuk Res. 2010; 34: 605-609.

21 Slovak ML, Kopecky KJ, Cassileth PA, et al. Karyotypic analysis predicts outcome of preremission and postremission therapy in adult acute my eloid leukemia: a Southwest Oncology Group/Eastern Cooperative Oncology Group Study. Blood. 2000; 96: 4075-4083.

22 Holowiecki J, Grosicki S, Giebel S, et al. Cladribine, but not fludarabine, added to daunorubicin and cytarabine during induction prolongs survival of patients with acute myeloid leukemia: a multicenter, randomized phase III study. J Clin Oncol. 2012; 30: 2441-2448.

23 Mosser DD, Caron AW, Bourget $L$, et al. Role of the human heat shock protein hsp70 in protection against stress induced apoptosis. Mol Cell Biol. 1997; 17: 5317-5327.

24 Ciocca DR, Calderwood SK. Heat shock proteins in cancer: diagnostic prognostic, predictive, and treatment implications. Cell Stress Chaperones. 2005; 10: 86-103.

25 Liu FF, Miller N, Levin W, et al. The potential role of HSP70 as an indicator of response to radiation and hyperthermia treatments for recurrent breast cancer. Int J Hyperthermia. 1996; 12: 197-208.

26 Chauhan D, Li G, Auclair D, Hideshima T, et al. Identification of genes regulated by 2-methoxyestradiol (2ME2) in multiple myeloma cells using oligonucleotide arrays. Blood. 2003; 101: 3606-3614.

27 Chant ID, Rose PE, Morris AG. Analysis of heat shock protein expression in myeloid leukemia cells by flow cytometry. $\mathrm{Br} \mathrm{J}$ Haematol. 1995; 90 163-168.

28 Dempsey NC, Leoni F, Ireland HE, et al. Differential heat shock protein localization in chronic lymphocytic leukemia. J Leukoc Biol. 2010; 87: 467-476.

29 Reikvam H, Hatfield KJ, Ersvaer $E$, et al. Expression profile of heat shock proteins in acute myeloid leukaemia patients reveals a distinct signature strongly associated with FLT3 mutation status - consequences and potentials for pharmacological intervention. $\mathrm{Br} \mathrm{J}$ Haematol. 2012; 156 $468-480$.

30 Gastpar R, Gehrmann M, Bausero MA, et al. Heat shock protein 70 surface-positive tumor exosomes stimulate migratory and cytolytic activity of natural killer cells. Cancer. Res. 2005; 65: 5238-5247.

31 Wells $A D$, Malkovsky M. Heat shock proteins, tumor immunogenicity and antigen presentation: an integrated view. Immunol Today. 2000; 21 129-132.

32 Massa C, Guiducci C, Arioli I, et al. Enhanced efficacy of tumor cell vaccines transfected with secretable HSP70. Cancer Res. 2004; 64: $1502-1508$. 
33 Jarjour WN, Jeffries BD, Davis JS 4th, et al. Autoantibodies to human stress proteins. A survey of various rheumatic and other inflammatory diseases. Arthritis Rheum. 1991; 34: 1133-1138.

34 Conroy SE, Sasieni PD, Fentiman I, et al. Autoantibodies to the 90kDa heat shock protein and poor survival in breast cancer patients. Eur J Cancer. 1998; 34: 942-943

35 Korneeva I, Bongiovanni AM, Girotra M, et al. IgA antibodies to the 27 $-\mathrm{kDa}$ heat-shock protein in the genital tracts of women with gynecologic cancers. Int J Cancer. 2000; 87: 824-828. 


\title{
Znaczenie prognostyczne oceny stężeń antygenu i przeciwciał przeciwko HSP70 u chorych na ostre białaczki szpikowe o pośrednim i niekorzystnym ryzyku cytogenetycznym
}

\author{
Jarosław Piszcz ${ }^{1}$, Łukasz Bołkun', Edyta Cichocka', \\ Marzenna Galar', Adam Hołownia², Janusz Kłoczko' \\ 1 Klinika Hematologii, Uniwersytet Medyczny w Białymstoku, Białystok \\ 2 Zakład Farmakologii Klinicznej, Uniwersytet Medyczny w Białymstoku, Białystok
}

\section{SŁOWA KLUCZOWE}

białko szoku cieplnego, HSP70, ostra białaczka szpikowa, przeciwciała anty-HSP70
Adres do korespondencji: dr n. med. Jarosław Piszcz, Klinika Hematologii, Uniwersytet Medyczny w Białymstoku, ul. Skłodowskiej-Curie 24, 15-276 Bialystok, tel.: 85-746-86-03, faks: $85-744-70-26$ e-mail: jaroslaw.piszcz@gmail.com Praca wpłynęła: 22.12.2013. Przyjęta do druku: 19.03.2014 Publikacja online: 21.03.2014. Nie zgłoszono sprzeczności interesów.

Pol Arch Med Wewn. 2014; 124 (4): 165-172

Copyright by Medycyna Praktyczna, Kraków 2014

\section{STRESZCZENIE}

WPROWADZENIE Nadekspresja białek szoku cieplnego (heat shock proteins - HSPs) występuje w wielu chorobach nowotworowych i jest związana z proliferacją, różnicowaniem, inwazyjnością, zdolnością tworzenia przerzutów, śmiercią oraz rozpoznawaniem komórek guza przez układ odpornościowy. Istnieją doniesienia o przydatności oznaczeń HSPs jako wskaźnika prognostycznego całkowitego przeżycia pacjentów z chorobami nowotworowymi.

CELE Celem pracy było oznaczanie stężeń antygenu białka HSP70 oraz przeciwciał anty-HSP70 we krwi obwodowej chorych na ostre białaczki szpikowe (acute myeloid leukemia - AML) oraz ocena jego przydatności.

PACJENCI I METODY Badanie przeprowadzono u 80 pacjentów z AML o pośrednim i wysokim ryzyku cytogenetycznym, planowanych do przeszczepienia allogenicznego komórek krwiotwórczych poprzedzonego intensywną chemioterapią. Stężenie antygenu HSP70 i przeciwciał anty-HSP70 w osoczu mierzono za pomocą testu immunoenzymatycznego. Dodatkowo stężenie antygenu mierzono za pomocą metody Western blot. Grupę kontrolną stanowili zdrowi ochotnicy.

WYNIKI U pacjentów z AML wykazano znamiennie wyższe stężenie przeciwciał anty-HSP70 w porównaniu do grupy kontrolnej. Stężenie antygenu HSP70 i przeciwciał anty-HSP70, a odpowiedzią na leczenie po chemioterapii indukującej remisję. Niemniej jednak chorzy z wysokim stężeniem antygenu HSP70 i niskim poziomem przeciwciał anty-HSP70 cechowali się istotnie krótszym czasem całkowitego przeżycia. WNIOSKI Przeprowadzone badanie sugeruje, że antygen HSP70 i przeciwciała anty-HSP70 mogą stanowić przydatny marker niekorzystnego rokowania u chorych na AML. 